\title{
PENGENAAN PAJAK PENGHASILANTERHADAP PELAKU USAHA JASA PROMOSI MELALUI MEDIA SOSIAL
}

\author{
Michael Lianwar Antolis, Ida Ayu Putu Widiati, I Putu Gede Seputra \\ Fakultas Hukum, Universitas Warmadewa, Denpasar-Bali, Indonesia \\ michaelantolis8@gmail.com, idiati_dayu@yahoo.co.id, gamyongputu@gmail.com
}

\begin{abstract}
Abstrak
Pajak penghasilan adalah pajak yang diberlakukan kepada orang/badan usaha atas penghasilan yang didapatkan dalam tahun pajak. Pelaku usaha jasa promosi adalah subjek pajak yang memperoleh pendapatan yang besarnya melebihi dari pendapatan yang tidak dikenakan pajak dan penghasilan tersebut didapatkan dari kegiatan melakukan promosi atas suatu barang atau jasa melalui media sosial, seperti instagram, YouTube, Whats App atau jenis media sosial lainnya. Tujuan penelitian ini untuk mengkaji pengaturan pajak penghasilan dalam kegiatan usaha jasa promosi melalui media sosial serta mekanisme pemungutan pajak penghasilan terhadap terhadap pelaku usaha jasa promosi melalui media sosial. Penelitian ini menggunakan metode penelitian hukum normatif, dengan bahan hukum yang terdiri dari bahan hukum primer dan bahan hukum sekunder. Pengumpulan bahan hukum dalam penelitian ini dilakukan dengan metode pencatatan. Metode analisa bahan hukum yang digunakan adalah teknik argumentatif. Hasil penelitian mengungkapkan bahwa pengaturan pajak penghasilan dalam kegiatan usaha jasa promosi melalui media sosial dalam hal ini YouTuber ataupun Selebgram yaitu dikenakan pajak penghasilan bagi mereka yang penghasilannya melebihi Penghasilan Tidak Kena Pajak (PTKP) berdasarkan Peraturan Dirjen Pajak Nomor PER-17/PJ/2015.
\end{abstract}

Kata Kunci: Jasa Promosi Media Sosial, Pajak Penghasilan, Pengenaan Pajak

\begin{abstract}
Income tax is a tax imposed on individuals/business entities on income earned in the tax year. Promotional service business actors are tax subjects who earn income that exceeds the non-taxable income and the income is obtained from activities promoting goods or services through social media, such as Instagram, YouTube, WhatsApp or other types of social media. The purposes of this study are to examine the regulation of income tax in promotional services business activities through social media as well as the mechanism for collecting income taxes against business actors in promotional services through social media. This study uses normative legal research methods, with legal materials consisting of primary legal materials and secondarylegal materials. The collection of legal materials in this study was carried out by the recording method. The legal material analysis method used is argumentative technique. The result of the study shows that the regulation of income tax in promotional service business activities through social media, in this case YouTubers or Celebrities, is subject to income tax for those whose income exceeds Non-Taxable Income (PTKP) based on the Regulation of the Director General of Taxes Number PER-17/PJ/2015.
\end{abstract}

Keywords: Social Media Promotion Services, Income Tax, Tax Imposition

\section{PENDAHULUAN}

Pajak ada dalam masyarakat, yaitu jika ada masyarakat maka akan ada pajak dan sebaliknya jika tidak ada masyarakat maka pajak pun tidak akan ada. Pajak adalah masalah bagi setiap orang yang hidup dalam suatu negara dan masalah pajak juga masalah Negara yang bersangkutan. Penerimaan Negara bersumber dari pungutan pajak kepada warganegara yang hidup dalam suatu negara dan hal ini berlaku hampir di seluruh negara di dunia. Uang hasil pungutan pajak tersebut dapat dipergunakan oleh pemerintah untuk membiayai kegiatan pemerintah demi terselenggaranya kepentingan umum. Dikarenakan pajak adalah sumber pendapatan yang penting, maka pemerintah dalam melakukan pemungutan pajak harus didasarkan keadilan serta memberikan kepastian hukum bagi para wajib pajak. Hal ini tertuang di dalam UUD NRI pasal 23 ayat (a) yang berbunyi "Pajak dan pungutan lain yang bersifat memaksa untuk keperluan negara diatur dengan Undang-undang."

Menurut ketentuan PasaI 1 ayat 1 Undang-undang 16/2009 yang selanjutnya disingkat dengan UU KUP, bahwa pajak adalah kontribusi wajib kepada negara yang terutang oleh orang pribadi atau badan yang bersifat memaksa berdasarkan Undang-undang, dengan tidak mendapatkan imbalan 
secara langsung dan digunakan untuk keperluan Negara bagi sebesar-besarnya kemakmuran rakyat. Undang-undang perpajakan mengatur mengenai jaminan atau kepastian tentang terpenuhinya kewajiban dan hak dalam perpajakan. Terbitnya UU perpajakan terutama yang mengatur mengenai pajak penghasilan, maka pelaku usaha diharapkan lebih termotivasi untuk melakukan pembayaran pajak sesuai dengan peraturan yang sudah berlaku demi meningkatkan kemakmuran rakyat.

Seiringnya perkembangan waktu, perkembangan internet telah menyeruak ke seluruh dunia termasuk Indonesia. Pemakaian jasa internet ini mengingat dengan cepat di Indonesia (Sitompul, 2004). Meningkatnya penggunaan internet di Indonesia juga memberikan dampak pada dunia bisnis seperti kegiatan yang dapat dilakukan dalam internet ialah e-commerce adalah kegiatan perdagangan yang terdiri dari kegiatan jual-beli barang dan/atau jasa dengan menggunakan media internet. Selain itu, manusia menciptakan sebuah terobosan terbaru yang memiliki tujuan untuk mempermudah setiap transaksi keuangan berbasis Internet.

Jasa promosi melalui media sosial semakin marak digunakan. Adanya kemungkinan pendapatan dari pajak yang cukup besar, Ditjen Pajak mempelajari tata cara pengenaan pajak dari bidang ini, mengingat pemungutan pajak dari jasa promosi melalui media sosial ini hanya berdasarkan pada penyampaian SPT. Terkait pajak, maka terdapat dua hal penting yaitu subjek pajak dan objek pajak. Subjek pajak adalah segala sesuatu yang mempunyai potensi untuk memperoleh penghasilan dan menjadi sasaran untuk dikenakan Pajak Penghasilan (Resmi, 2013). Selain itu juga Undangundang perpajakan menyebutkan, bahwa siapapun yang memiliki penghasilan maka merupakan objek pajak. Menurut Ilyas \& Burton (2007) wajib pajak (WP) telah menjadi kontributor pembangunan demi eksistensi Negara, dan terdapat hal yang dapat dituntut dari wajib Pajak yakni:

1. Dituntut kepatuhan (compliance) wajib pajak dalam membayar pajak yang dilaksanakan dengan kesadaran penuh.

2. Dituntut tanggung jawab (responsibility) wajib pajak dalam menyampaikan Surat Pemberitahuan tepat waktu.

3. Dituntut kejujuran (honesty) wajib pajak dalam mengisi Surat Pemberitahuan sesuai dengan keadaan yang sebenarnya.

4. Memberikan sanksi (law enforcement) yang lebih berat kepada wajib pajak yang tidak taat pada ketentuan yang berlaku.

Di Indonesia untuk memungut pajak dari masyarakat, saat ini sebagian besar menggunakan self assessment, dimana wajib pajak sendirilah yang menghitung dan menilai pemenuhan kewajiban perpajakannya (Devano \& Rahayu, 2006). Terkait sistem pemungutan pajak, maka dapat dilakukan dengan tiga cara, yaitu:

1. "Official Assessment System, Sistem ini merupakan sistem pemungutan pajak yang memberi wewenang kepada pemerintah (fiskus) untuk menentukan besarnya pajak yang terutang."

2. "Self Assessment System, Sistem ini merupakan pemungutan pajak yang memberi wewenang, kepercayaan, tanggung jawab kepada Wajib Pajak untuk menghitung, memperhitungkan, membayar, dan melaporkan sendiri besarnya pajak yang harus dibayar."

3. "Withholding System, Sistem ini merupakan sistem pemungutan pajak yang memberi wewenang kepada pihak ketiga untuk memotong atau memungut besarnya pajak yang terutang oleh wajib pajak." (Mardiasmo, 2005).

Sistem self assessment dalam pemungutan pajak inilah yang mengakibatkan tidak efektifnya pelaksanaan pengenaan pajak. Walau pemerintah telah melonggarkan dengan memberikan peringatan melalui SPT, tetapi masih banyak wajib pajak yang lalai untuk membayar pajak dan tidak sedikit yang cenderung menghindari kewajiban tersebut.

Penelitian terdahulu yang relevan dengan penelitian ini mengungkapkan bahwa dasar hukum yang mengatur mengenai pajak untuk selebgram dan youtuber diatur dalam Undang-undang Nomor 16 Tahun 2009 Tentang Ketentuan Umum dan Tata Cara Perpajakan (Angin \& Gaol, 2021) (Vikansari \& Parsa, 2019). Sedangkan menurut Susilo (2020) berpendapat bahwa tidak semua yang menjadi youtuber dapat dikenakan pajak penghasilan hanya yang memenuhi syarat-syarat tertentu saja lah yang dapat dikenakan pajak penghasilan. Dari fenomena tersebut maka ingin dilakukan penelitian yang bertujuan untuk menjelaskan pengaturan pajak penghasilan dalam kegiatan usaha jasa promosi melalui media sosial serta mekanisme pemungutan pajak penghasilan terhadap terhadap pelaku usaha jasa promosi melalui media sosial. 


\section{METODE PENELITIAN}

Penelitian ini menggunakan metode penelitian normative dengan pendekatan yang digunakan yaitu pendekatan undang-undang (statute approach) dan pendekatan konseptual (conceptual approach). Penelitian hukum normatif adalah penelitian yang meneliti hukum dari perspektif internal dengan objek penelitiannya adalah norma hukum, fungsinya untuk memberikan argumentasi yuridis ketika terjadi kekosongan, kekaburan dan konflik norma (Diantha, 2016). Bahan hukum terdiri dari bahan hukum primer yang didapat dengan menganalisis peraturan perundang-undangan, risalah resmi, dan beberapa keputusan-keputusan yang menyangkut dengan judul tulisan ini. Bahan hukum sekunder didapat dari menganalisis buku-buku, jurnal-jurnal dan hasil-hasil penelitian terdahulu yang memiliki keterkaitan dengan judul penulisan ini. Metode pengumpulan bahan hukum menggunakan teknik pencatatan dan dokumentasi yang kemudian analisis dengan teknik argumentatif.

\section{HASIL DAN PEMBAHASAN}

\section{Pengaturan Pajak Penghasilan dalam Kegiatan Usaha Jasa Promosi Melalui Media Sosial}

Perdagangan online atau e-commerce, pada awalnya digunakan untuk transaksi bisnis antar perusahaan-perusahaan besar, antar perbankan, serta institusi, namun pada perkembanganya, fokusnya bergeser kepada konsumen-konsumen individual bukan lagi perusahaan-perusahaan besar dan institusi. Pergeseran ini menjadikan terjadi peningkatan transaksi melalui media ecommerce, juga diikuti dengan peningkatan transaksi dengan menggunakan media sosial, yaitu melalui instagram, facebook, youtube, whatsapp dan aplikasi media sosial lainnya. Jika ditinjau dari biaya operasional yang dikeluarkan, transaksi online menghabiskan biaya operasional yang lebih rendah dibandingkan transaksi secara konvensional. Jika ditinjau dari omset yang didapatkan, transaksi online menghasilkan omset yang lebih besar dibandingkan omset yang dihasilkan dari transaksi konvensional karena itu perlu dilakukan upaya untuk pemenuhan kewajiban pajak dari sektor perdagangan online ini.

Pajak Penghasilan adalah pajak yang yang dikenakan kepada Wajib Pajak dari penghasilan yang diperoleh. Menurut PasaI 4 UU PPh, Penghasilan adalah "setiap tambahan kemampuan ekonomis untuk yang diterima atau diperoleh oleh Wajib Pajak, baik yang berasal dari Indonesia maupun luar Indonesia yang dapat digunakan untuk konsumsi maupun menambah kekayaan Wajib Pajak yang bersangkutan, dengan nama dan dalam bentuk apa pun."

Berdasarkan pengertian penghasilan menurut Pasal 4 UU PPh, Rahayu (2010) berpendapat, bahwa terdapat sejumlah unsur, yakni:

1. Tambahan kemampuan ekonomis, yaitu segala sesuatu yang dapat menambah kemampuan ekonomis, atau kemampuan seseorang untuk menguasai atau memiliki sesuatu dapat dikenakan pajak. Bentuk penambahan kemampuan ekonomis ini bisa berupa penghasilan atau imbalan seperti gaji, upah, hadiah, laba usaha, dividen dan lainnya merujuk pada Pasal 4 ayat $1 \mathrm{UU} \mathrm{PPh}$.

2. Diterima oleh Wajib Pajak adalah orang atau badan yang memenuhi syarat- syarat objektif, yaitu menerima penghasilan lebih dari PTKP (Penghasilan Tidak Kena Pajak).

3. Berasal dari Indonesia atau luar Indonesia, penambahan kemampuan ekonomis yang diterima Wajib Pajak bisa berasal dari Indonesia (Wajib Pajak dalam negeri) maupun dari luar Indonesia (Wajib Pajak Luar Negeri) Wajib Pajak Dalam Negeri adalah siapa pun yang memperoleh atau menerima penghasilan melebihi PTKP (Penghasilan Tidak Kena Pajak), dan Wajib Pajak Luar Negeri adalah siapa pun yang menerima atau memperoleh penghasilan dari sumber- sumber yang ada di Indonesia yang tidak ada batas minimumnya PTKP.

4. Dapat digunakan untuk konsumsi atau menambah kekayaan Wajib Pajak, tambahan kemampuan ekonomis yang diterima Wajib Pajak dapat digunakan untuk konsumsi dan menambah kekayaan Wajib Pajak. Artinya segala tambahan kemampuan ekonomis tersebut bisa dinikmati oleh Wajib Pajak.

5. Dengan nama dan bentuk apapun, penambahan kemampuan ekonomis bias dalam nama dan bentuk apapun, seperti barang ataupun jasa.

\section{Mekanisme Pemungutan Pajak Penghasilan Terhadap Terhadap Pelaku Usaha Jasa Promosi Melalui Media Sosial}

Pajak endorsement adalah pajak penghasilan dari transaksi online melalui media sosial, Pajak ini memungut penghasilan atau laba yang diterima dan diperoleh orang pribadi maupun badan. Adapun 
penerima penghasilan yang dipotong PPh PasaI 21/26, sebagaimana diatur pada PasaI 3 PDJP No.16 PER-16/PJ/2016, yang menentukan bahwa penerima Penghasilan yang dipotong PPh Pasal 21 dan/atau PPh Pasal 26 adalah orang pribadi yang merupakan:

1. Pegawai.

2. Penerima uang pesangon, pensiun atau uang manfaat pensiun, tunjangan hari tua, atau jaminan hari tua, termasuk ahli warisnya juga merupakan wajib pajak PPh Pasal 21.

3. Wajib pajak PPh 21 kategori bukan pegawai yang menerima atau memperoleh penghasilan sehubungan dengan pemberian jasa, meliputi:

1) Tenaga ahli yang melakukan pekerjaan bebas, yang terdiri dari pengacara, akuntan, arsitek, dokter, konsultan, notaris, penilai dan aktuaris;

2) Pemain musik, pembawa acara, penyanyi, pelawak, bintang film, bintang sinetron, bintang iklan, sutradara, kru film, foto model, peragawan/peragawati, pemain drama, penari, pemahat, pelukis dan seniman lainnya;

3) Olahragawan;

4) Penasihat, pengajar, pelatih, penceramah, penyuluh, dan moderator;

5) Pengarang, peneliti, dan penerjemah;

6) Pemberi jasa dalam segala bidang termasuk teknik, komputer dan sistem aplikasinya, telekomunikasi, elektronika, fotografi, ekonomi, dan sosial serta pemberi jasa kepada suatu kepanitiaan;

7) Agen iklan;

8) Pengawas atau pengelola proyek;

9) Pembawa pesanan atau menemukan langganan atau yang menjadi perantara;

10) Petugas penjaja barang dagangan;

11) Petugas dinas luar asuransi; dan/atau

12) Distributor perusahaan multilevel marketing atau direct selling dan kegiatan sejenis lainnya

4. Anggota dewan komisaris atau dewan pengawas yang tidak merangkap sebagai Pegawai Tetap pada perusahaan yang sama juga merupakan Wajib Pajak PPh Pasal 21. Selain itu, kategori di bawah ini juga termasuk Wajib Pajak PPh 21.

5. Mantan pegawai; dan/atau

6. Wajib Pajak PPh Pasal 21 kategori peserta kegiatan yang menerima atau memperoleh penghasilan sehubungan dengan keikutsertaannya dalam suatu kegiatan, antara lain:

1) Peserta perlombaan dalam segala bidang, antara lain perlombaan olahraga, seni, ketangkasan, ilmu pengetahuan, teknologi dan perlombaan lainnya;

2) Peserta rapat, konferensi, sidang, pertemuan, atau kunjungan kerja;

3) Peserta atau anggota dalam suatu kepanitiaan sebagai penyelenggara kegiatan tertentu;

4) Peserta pendidikan dan pelatihan; atau

5) Peserta kegiatan lainnya." adalah:

Terkait pemberi kerja yang memotong PPh Pasal 21/26, maka hal-hal yang harus dilakukan

1. Melakukan pemotongan PPh Pasal21 sesuai dengan ketentuan tarif PPh yang berlaku;

2. Membuat bukti potong PPh Pasal 21 melalui aplikasi e-SPT PPh Pasal21;

3. Melakukan penyetoran PPh Pasal 21 yang telah dipotong tersebut menggunakan kode billing dengan kode MAP dan kode jenis setoran 411121-100. Penyetoran dilakukan paling lambat tanggal 10 bulan berikutnya. Misalnya pemotongan PPh Pasal 21 dilakukan pada bulan April 2020, maka penyetoran PPh-nya adalah paling lambat dilakukan pada tanggal 10 Mei 2020; dan

4. Menyampaikan laporan SPT Masa PPh 21 secara daring melalui saluran e filing Direktorat Jenderal Pajak di laman pajak.go.id atau Penyedia Jasa Aplikasi Perpajakan (PJAP) resmi yang ditunjuk.

Pengaturan mengenai pajak terhadap para pelaku usaha yang melakukan promosi melalui media sosial dalam hal ini dapat berprofesi sebagai YouTuber atau Selebgram, maka dibagi dua, yang pertama adalah YouTuber dan Selebgram yang bekerja secara independen atau freelance, dan yang kedua adalah YouTuber dan Selebgram yang berada di bawah agensi (pihak ketiga). Pengenaan Pajak pada profesi ini mengacu pada PDJP No.PER-17/PJ/2015 yakni mengenakan pajak sebesar 50\%. 
Perhitungan PPh profesi YouTuber dan Selebgram merujuk kepada pekerjaan bebas yang tidak termasuk dalam skema PPh Final yang diatur dalam PasaL 2 ayat (4) PP 23/2018, yang memberikan ruang lingkup pekerjaan bebas antara lain: pemain, musik, pembawa acara, penyanyi, pelawak, bintang film, bintang sinetron, bintang iklan, sutradara, kru film, foto model, peragawan/peragawati, pemain drama, dan penari, maka perhitungannya bias dipilih antara menggunakan norma atau menggunakan pembukuan.

\section{SIMPULAN DAN SARAN}

\section{Simpulan}

Berdasarkan pembahasan yang telah dilakukan, maka penelitian dapat disimpulkan bahwa pengaturan pajak penghasilan dalam kegiatan usaha jasa promosi melalui media sosial dalam hal ini YouTuber ataupun Selebgram yaitu dikenakan pajak penghasilan bagi mereka yang penghasilannya melebihi Penghasilan Tidak Kena Pajak (PTKP). Berdasarkan ketentuan pada UU PPh dan PDJP No.16: PER-16/PJ/2016, maka untuk YouTuber dan Selebgram yang bekerja secara independen atau freelance, maka ketentuan PPh yang berlaku adalah Pasal 21 UU PPh yang biasa digunakan untuk para pekerja seni dan para freelancer. Untuk para YouTuber dan Selebgram yang berada di bawah naungan agensi atau perusahaan, maka ketentuan pajak penghasilan yang berlaku adalah sama dengan karyawan yang bekerja di kantor pada umumnya yaitu ketentuan Pasal $23 \mathrm{UU}$ PPh. Adapun mekanisme pemungutan pajak penghasilan terhadap pelaku usaha jasa promosi melalui media sosial dalam hal ini YouTuber ataupun Selebgram yaitu merujuk kepada Peraturan Dirjen Pajak Nomor PER-17/PJ/2015 tentang Norma Penghitungan Penghasilan Neto yakni sebesar 50\% x penghasilan bruto. Adapun cara menghitung PPh YouTuber dan Selebgram, menggunakan Rumus perhitungan $\mathrm{PPh}$, yaitu $=(\mathrm{PTKP}) \times$ Tarif $\mathrm{PPh}$ Pasal 17.

\section{Saran}

Kepada pemerintah khususnya Dirjen Pajak perlu dibuatkan peraturan khusus mengenai pengenaan pajak penghasilan terkait endorsement yang dilakukan pada media sosial serta meningkatkan pelayanan terhadap wajib pajak dalam melaksanakan kewajiban membayar pajak dan mengadakan sosialisasi kepada masyarakat, agar terbangun kesadaran dan kepatuhan WP dalam membayar pajak dan bagi para pelaku jasa promosi melalui media sosial baik YouTuber ataupun Selebgram haruslah tunduk pada semua peraturan yang berlaku, terkait aturan perpajakan di Indonesia.

\section{DAFTAR PUSTAKA}

Angin, A. sriwahyuni B. P., \& Gaol, H. H. H. L. (2021). Urgensi Penarikan Pajak Penghasilan Profesi Youtuber dan Selebgram Sebagai Upaya Mendorong Stabilisasi Perekonomian Pasca Pandemi. Jurnal Pacta Sunt Servanda, 2(2), 77-87.

Devano, S., \& Rahayu, S. K. (2006). Perpajakan : Konsep, Teori dan Isu. Kencana, Jakarta.

Diantha, I. M. P. (2016). Metodologi Penelitian Hukum Normatif dalam Justifikasi Teori Hukum. Prenada Media Group, Jakarta.

Ilyas, W., \& Burton, R. (2007). Hukum Pajak. Salemba Empat, Jakarta.

Mardiasmo. (2005). Perpajakan. Andi, Yogyakarta.

Rahayu, S. K. (2010). Perpajakan Indonesia: Konsep dan Aspek Formal. Graha Ilmu, Yogyakarta.

Resmi, S. (2013). Perpajakan; Teori dan Kasus. Salemba Empat, Jakarta.

Sitompul, A. (2004). Hukum Internet: Pengenalan Mengenai Masalah Hukum di Cyberspace. PT. Citra Aditya Bakti, Bandung.

Susilo, W. (2020). Tinjauan Yuridis Pemungutan Pajak Penghasilan Terhadap Youtuber Menurut Undang-undang Nomor 36 Tahun 2008 Tentang Pajak Penghasilan (PPh). Jurnal IUS, 8(1), 114.

Vikansari, N. P. S., \& Parsa, I. W. (2019). Pengawasan Pengenaan Pajak Penghasilan Terhadap Youtubers sebagai Pelaku Influencer di Platform Media Sosial Youtube. Jurnal Kertha Negara, 7(2), 1-15. 